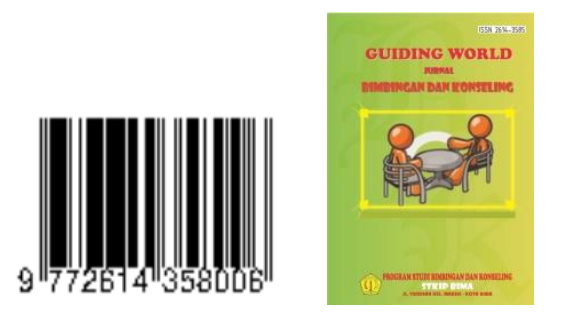

\title{
Efektivitas Penggunaan Teknik Role Playing Untuk Mengurangi Perilaku Bullying Pada Remaja Di Desa Rabakodo
}

\author{
Mardiyanti, Faijin, Nurhayati \\ Prodi Bimbingan dan Konseling, Sekolah Tinggi Keguruan Dan Ilmu Pendidikan (STKIP Bima) \\ Email: wongfaijin@gmail.com
}

\begin{abstract}
Abstrak
\end{abstract}
Banyak permasalahan yang timbul, salah satunya permasalahan bullying yang terjadi di Desa Rabakodo, Kecamatan Woha, Kabupaten Bima. Permasalahan ini sangat bertentangan dengan Undang-Undang No. 23 tahun 2002 pasal 4 tentang perlindungan anak. Berdasarkan masalah ini, maka tujuan penelitian adalah untuk mengetahui seberapa besar efektivitas penggunaaan teknik role playing untuk mengurangi perilaku bullying pada remaja di Desa Rabakodo. Penelitian ini dilaksanakan di Desa karena pada saat peneliti akan melakukan penelitian, muncullah wabah covid-19 yang mengakibatkan lingkup pendidikan diliburkan guna untuk menjaga tersebarnya wabah tersebut. Sehingga penelitian ini dialihkan di lingkungan sosial yaitu di Desa Rabakodo, Kecamatan Woha, Kabupaten Bima. Remaja adalah masa peralihan antara masa anak-anak menuju masa dewasa. Dimana masa remaja ini psikologi individu sedang mengalami perubahan baik perubahan yang kearah positif maupun negatif. Pada umumnya masa remaja berada pada proses peralihan dan cenderung memiliki sifat persaingan yang tinggi sehingga perilaku bullying sering terjadi. Penelitian ini dilaksanakan untuk menguji efektivitas penggunaan teknik role playing untuk mengurangi perilaku bullying pada remaja di Desa Rabakodo. Jumlah subyek dalam penelitian ini adalah 7 orang remaja dengan ciri-ciri yang sama yaitu memiliki perilaku bullying. Teknik role playing adalah teknik pembelajaran yang diarahkan kepada remaja untuk bermain peran tentang suatu topik yang sesuai dengan masalah yang akan dibahas. Sedangkan perilaku bullying adalah perilaku agresif yang dilakukan oleh seseorang atau sekelompok orang kepada seorang korban yang tidak mampu mempertahankan dirinya. Peneliti menggunakan jenis penelitian pre-eksperimenone group pretest-posttest design (tes awal-tes akhir kelompok tunggal). Pada penelitian pre-eksperimen, peneliti memberikan perlakuan pada kelompok eksperimen, tetapi sebelumnya diukur atau dites dahulu (pretest) selanjutnya diberikan perlakuan, kemudian diukur atau dites kembali (posttest). Teknik pengambilan sampel adalah teknik purposivesampling. Instrumen penelitian menggunakan lembar penilaian diri, observasi dan wawancara. Teknik analisis data menggunakan uji $t$. Hasil analisis data menemukan bahwa nilai rata-rata pretest adalah $69,85 \%$ sedangkan nilai rata-rata posttest adalah $56,57 \%$. Nilai $t_{\text {hitung }}$ adalah 2,309\% apabila dikonsultasikan dengan nilai $t_{\text {tabel }}$ maka nilai $t_{\text {tabel }}$ adalah 1,943\%. Sehingga dapat disimpulkan bahwa nilai $t_{\text {hitung }}$ lebih besar daripada nilait $_{\text {tabel. }}$ Maka hal itu bermakna bahwa hipotesis nol $\left(H_{0}\right)$ yang berbunyi penggunaan teknik role playing tidak efektif untuk mengurangi perilaku bullying 


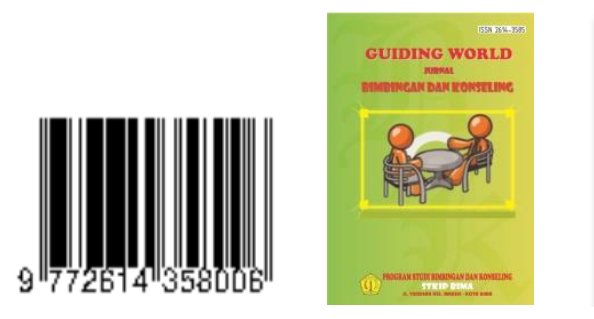

pada remaja, ditolak. Sedangkan hipotesis alternatif $\left(H_{a}\right)$ yang berbunyi penggunaan teknik role playing efektif untuk mengurangi perilaku bullying pada remaja, diterima.

Kata Kunci: Role Playing, Perilaku Bullying, Remaja

\section{PENDAHULUAN}

Tujuan umum pelayanan bimbingan dan konseling pada dasarnya sejalan dengan tujuan pendidikan itu sendiri karena bimbingan dan konseling merupakan bagian integral dari sistem pendidikan. Pada Undang-Undang Nomor 2 tahun 1989 tentang Sistem Pendidikan Nasional disebutkan bahwa tujuan pendidikan adalah terwujudnya manusia Indonesia seutuhnya yang cerdas, yang beriman dan taqwa kepada Tuhan Yang Maha Esa dan berbudi pekerti luhur, memiliki pengetahuan dan keterampilan, kesehatan jasmani dan rohani, kepribadian yang mantap dan mandiri serta rasa tanggung jawab kemasyarakatan dan kebangsaan. Secara umum, Bimbingan dan Konseling adalah suatu proses pemberian bantuan kepada individu secara berkelanjutan dan sistematis, yang dilakukan oleh seorang ahli yang telah mendapat latihan khusus untuk itu, dengan tujuan agar individu dapat memahami dirinya, lingkungannya, serta dapat mengarahkan diri dan menyesuaikan diri dengan lingkungan untuk mengembangkan potensi dirinya secara optimal untuk kesejahteraan dirinya dan kesejahteraan masyarakat. Masa remaja merupakan masa peralihan antara masa kehidupan anak-anak dan masa kehidupan orang dewasa yang ditandai dengan pertumbuhan dan perkembangan biologis dan psikologis. Secara biologis ditandai dengan tumbuh dan berkembangnya seks primer dan seks sekunder. Sedangkan secara psikologis ditandai dengan sikap dan perasaan, keinginan dan emosi yang labil atau tidak menentu. Menurut Prayitno dan Amti (2004: 309) bimbingan kelompok merupakan layanan bimbingan yang diberikan dalam suasana kelompok sehingga dengan dilaksanakannya layanan bimbingan kelompok, peserta didik dapat memperoleh pengalaman, pengetahuan dan informasi yang berkaitan dengan perilaku sosial peserta didik di sekolah.

Pada layanan bimbingan kelompok ada banyak teknik yang dapat digunakan, salah satunya yaitu teknik role playing. Bermain peran (role playing) biasanya digunakan dalam bimbingan kelompok, dimana melibatkan orang lain. Anggota kelompok lain dapat berperan sebagai ego state yang bermasalah dengan anak. Anak tersebut dilatih dengan anggota kelompok untuk bertingkah laku sesuai dengan apa yang akan diuji coba di dunia nyata, anak dapat meningkatkan perasaannya sendiri serta perasaan orang lain dan anak mampu mengidentifikasi situasi-situasi dunia nyata dengan ide-ide orang lain. Teknik bermain peran (role playing) dalam penelitian ini diharapkan dapat mengurangi perilaku bullying dengan cara memainkan peran untuk meningkatkan beberapa aspek seperti aspek empati, keterampilan, interpersonal, kemampuan pengendalian diri dan sikap bertanggung jawab. Banyak permasalahan yang timbul, salah satunya permasalahan bullying di desa Rabakodo yang marak terjadi belakangan ini. Munculnya masalah bullying pada lingkungan masyarakat ini sangat bertentangan dengan isi Undang-Undang No. 23 tahun 2002 tentang perlindungan anak, pasal 4 yang berbunyi "setiap anak berhak untuk hidup, tumbuh, berkembang dan 


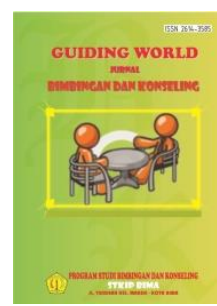

E-ISSN: 2614-3585

berpartisipasi secara wajar sesuai dengan harkat dan martabat kemanusian serta dapat perlindungan dari kekerasan dan diskriminasi".

Bullying berasal dari kata "bully" yang artinya penggertak atau orang yang menggangu orang lain yang lebih lemah. Bullying secara umum juga diartikan sebagai perpeloncoan, penindasan, pengucilan, pemalakan dan sebagainya. Perilaku bullying dilakukan dalam situasi dimana ada hasrat untuk melukai, menakuti atau membuat orang lain merasa tertekan, trauma, depresi dan tidak berdaya (Kamus Besar Bahasa Indonesia). Menurut Djuwita (2006) terjadinya bullying di sekolah merupakan suatu proses dinamika kelompok, dimana ada pembagian-pembagian peran. Peran-peran tersebut adalah bully, asisten bully, reinvorcer, victim, devender dan outsider. Bully yaitu peserta didik yang dikategorikan sebagai pemimpin yang berinisiatif dan aktif terlibat dalam perilaku bullying. Asisten bullying juga terlibat aktif dalam perilaku bullying, namun cenderung tergantung atau mengikuti perintah bully. Reinvorcer adalah mereka yang ada ketika kejadian bullying terjadi, ikut menyaksikan, menertawakan korban, memprovokasi bully, mengajak individu lain untuk menonton dan sebagainya. Sedangkan outsider (bystander) adalah orang-orang tahu bahwa hal itu terjadi, namun tidak melakukan apapun, seolah-olah tidak peduli.

Berdasarkan hasil pengamatan yang dilakukan oleh peneliti selama masa covid-19 di Desa Rabakodo Kecamatan Woha, terdapat beberapa anak yang menjadi korban bullying, sehingga mereka sulit untuk bergaul serta beradaptasi dengan yang lainnya. Remaja yang cenderung memiliki perilaku bullying berjumlah 7 orang dengan perilaku bullying fisik, verbal dan relasional. Hasil wawancara yang dilakukan dengan orang tua dari anak yang menjadi korban bullying di Desa Rabakodo Kecamatan Woha, terdapat beberapa perilaku bullying yang cenderung dilakukan oleh remaja di Desa Rabakodo. Bentuk perilaku bullying yang terjadi yaitu perilaku bullyingfisik (memukul dan menendang), perilaku bullying verbal (julukan nama dan mengejek) dan perilaku bullying relasional (pandangan sinis dan tawa mengejek. Rumusan masalah adalah seberapa besar efektivitas penggunaan teknik role playing untuk mengurangi perilaku bullying pada remaja di Desa Rabakodo. Tujuan penelitian yaitu untuk mengetahui seberapa besar efektivitas penggunaan teknik role playing untuk mengurangi perilaku bullying pada remaja di Desa Rabakodo. Hipotesis dalam penelitian ini (Ha) adalah penggunaan teknik role playing efektif untuk mengurangi perilaku bullying pada remaja di Desa Rabakodo.

\section{KERANGKA TEORITIS Tinjauan Role Playing}

Banyak materi belajar yang sulit diterima dan dijelaskan hanya menggunakan kata-kata. Ada beberapa metode yang dapat digunakan dalam pembelajaran, misalnya metode role playing, ceramah, pemberian tugas, eksperimen, tanya jawab dan masih banyak lagi metode yang dapat digunakan dalam pembelajaran. Penggunaan metode yang tepat, guru bimbingan dan konseling dapat menjelaskan sesuatu yang akan disampaikan dengan mudah dan dapat dipahami oleh individu. Teknik bermain peran (role playing) dalam penelitian ini diharapkan dapat mengurangi perilaku bullying dengan cara memainkan peran untuk meningkatkan beberapa aspek seperti aspek empati, keterampilan, interpersonal, kemampuan pengendalian diri dan sikap bertanggung jawab. Menurut Sugihartono (Arum Suryaningtyas, 2014: 27-28) teknik role playing merupakan metode pembelajaran melalui pengembangan imajinasi dan penghayatan anak dengan cara anak memerankan suatu tokoh hidup atau benda mati. Menurut 


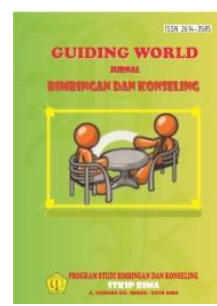

Wina Sanjaya (Arum Suryaningtyas, 2014: 27-28) teknik role playing adalah metode pembelajaran sebagai bagian dari bentuk simulasi yang diarahkan untuk mengkreasi peristiwa sejarah, mengkreasi peristiwa-peristiwa aktual atau kejadian-kejadian yang muncul pada masa mendatang.

Berdasarkan beberapa pengertian di atas, peneliti dapat menyimpulkan bahwa teknik role playing adalah teknik pembelajaran dalam bimbingan kelompok yang diarahkan untuk mengkreasi peristiwa sejarah, peristiwa aktual atau kejadian yang mungkin akan muncul pada masa mendatang, individu yang menjadi anggota kelompok akan berakting atau berperan tentang suatu topik atau situasi yang sesuai dengan masalah yang akan dibahas dalam bimbingan kelompok.

\section{Tujuan Role Playing}

Tujuan bermain peran secara umum adalah menggambarkan suatu peristiwa masa lampau atau dapat pula cerita dimulai dengan berbagai kemungkinan yang terjadi baik sekarang maupun mendatang, kemudian ditunjuk beberapa individu untuk melakukan peran sesuai dengan tujuan cerita.

Menurut Oemar Hamalik (Arum Suryaningtyas, 2014: 27-28) tujuan teknik role playing adalah untuk mengembangkan keterampilan-keterampilan interaktif atau keterampilanketerampilan reaktif, para peserta didik pengamat drama menyamakan diri dengan pelaku (actor) dan tingkah laku mereka, untuk mengembangkan prosedur-prosedur kognitif dan prinsip-prinsip yang mendasari perilaku keterampilan yang telah didramatiskan dan dapat memperbaiki keterampilan-keterampilan mereka dengan mengulanginya dalam penampilan berikutnya. Sedangkan menurut Nana Sudjana (Anis Denista Prahasti, 2016: 30) tujuan teknik role playing adalah sebagai berikut;1)Agar peserta didik dapat menghayati dan menghargai perasaan orang lain,2)Dapat belajar bertanggung jawab,3)Dapat belajar mengambil keputusan dalam situasi kelompok secara spontan,4)Merangsang kelas untuk berpikir dan memecahkan masalah.

\section{Tahapan Role Playing}

Terdapat tiga hal yang perlu diperhatikan oleh guru bimbingan dan konseling dalam penggunaan teknik role playing yaitu sebagai berikut; kualitas pemeran, analisis yang mengiringi pemeran dan persepsi peserta didik mengenai kesamaan permainan peranan dengan kehidupan nyata. Menurut Shaftels, tahap-tahap dalam penggunaan teknik role playing dapat dibagi menjadi sembilan tahapan yaitu sebagai berikut;1)Tahap Pemanasan: Mengidentifikasi dan mengenal masalah, Memperjelas masalah, Menafsirkan masalah, Menjelaskan role playing. 2)Memilih Partisipan: Menganalisis peran, Memilih pemain yang akan melakukan peran. 3)Mengatur Setting Tempat Kejadian: Mengatur sesi-sesi atau batasan tindakan, Menegaskan kembali peran, Lebih mendekat pada situasi yang bermasalah. 4)Menyiapkan Observer: Memutuskan apa yang akan dicari dan diamati, Memberi tugas pengamatan. 5)Pemeranan: Memulai role playing, Mengukuhkan role playing, Mengakhiri role playing. 6)Diskusi dan Evaluasi: Mereview pemeranan (kejadian, posisi dan kenyataan), Mendiskusikan fokus-fokus utama, Mengembangkan pemeranan selanjutnya.7)Pemeranan Kembali: Memainkan peran yang telah direvisi, Memberi masukan atau alternatif perilaku dalam langkah selanjutnya. 8)Diskusi dan Evaluasi: Mereview pemeranan (kejadian, posisi dan kenyataan), Mendiskusikan fokus-fokus utama, Mengembangkan pemerannya selanjutnya. 9)Berbagi Pengalaman dan Melakukan Generalisasi: Menghubungkan situasi 


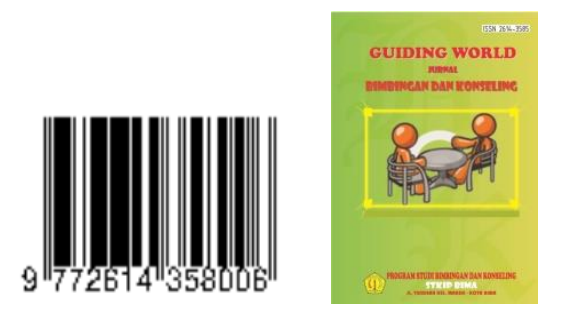

E-ISSN: 2614-3585

yang bermasalah dengan kehidupan sehari-hari serta masalah-masalah aktual dan menjelaskan prinsip-prinsip umum dalam tingkah laku.

\section{Kelebihan Teknik Role Playing}

Dalam teknik role playing terdapat beberapa kelebihan, adapun kelebihan teknik role playing adalah sebagai berikut: Individu melatih dirinya untuk memahami dan mengingat bahan yang akan didramakan atau diperankan. Sebagai pemain harus memahami dan menghayati isi cerita secara keseluruhan, terutama untuk materi yang harus diperankannya. Dengan demikian daya ingat dan keterampilan individu akan terlatih, Individu akan terlatih untuk berinisiatif dan berkreatif. Pada waktu bermain individu dituntut untuk mengemukakan pendapatnya sesuai dengan materi dan waktu yang tersedia, Bakat yang terpendam pada diri individu dapat dibina sehingga dimungkinkan akan muncul generasi seniman dari sekolah. Jika seni drama individu dibina dengan baik kemungkinan besar individu akan menjadi pemeran seni yang baik suatu saat, Kerja sama antar pemain dapat ditumbuhkan dan dibina dengan sebaik-baiknya untuk mendidik individu dalam menghargai karya atau hasil belajar peserta didik lain, Individu memperoleh pengalaman untuk menerima dan membagi tanggung jawab dengan sesamanya, Bahasa lisan dapat dibina menjadi bahasa yang baik agar mudah dipahami orang lain.

\section{Kelemahan Teknik Role Playing}

Selain terdapat kelebihan dalam teknik role playing, maka terdapat pula kelemahan dalam teknik role playing. Kelemahan dalam teknik role playing adalah sebagai berikut: Individu yang tidak ikut bermain peran menjadi kurang aktif, Banyak menghabiskan waktu, baik waktu persiapan dalam rangka pemahaman isi bahan pelajaran maupun pada pelaksanakan pertunjukan, Memerlukan tempat yang cukup luas, jika tempat bermain sempit menyebabkan gerak pemain kurang bebas.

\section{Cara Mengatasi Kelemahan Teknik Role Playing}

Usaha-usaha yang dapat dilakukan oleh guru bimbingan dan konseling dalam mengatasi kelemahan dari penggunaan teknik role playing adalah sebagai berikut;

a. Guru bimbingan dan konseling harus menerangkan kepada individu untuk memperkenalkan teknik role playing. Dengan teknik role playing, individu diharapkan dapat memecahkan masalah hubungan sosial yang aktual ada di masyarakat atau sesuai dengan masalah yang terdapat dalam pelajaran yang sedang diajarkan oleh guru. Kemudian guru menunjuk beberapa individu yang akan bermain peran, sedangkan individu yang menjadi penonton dengan tugas-tugas tertentu

b. Guru harus memilih masalah yang urgen, sehingga dapat menarik minat individu untuk mengikuti pembelajaran. Guru dapat menjelaskan dengan baik dan menarik, sehingga individu dapat terangsang untuk memecahkan masalah tersebut

c. Agar individu memahami peristiwanya, maka guru harus bisa menceritakan saat adegan berlangsung

d. Bobot atau luasnya bahan pelajaran yang akan didramakan harus sesuai dengan waktu yang tersedia. Oleh karena itu, harus diusahakan agar para pemain dapat berbicara dan melakukan gerakan sesuai dengan naskah cerita atau materi pembelajaran dan tidak keluar dari peran yang didapatnya. 

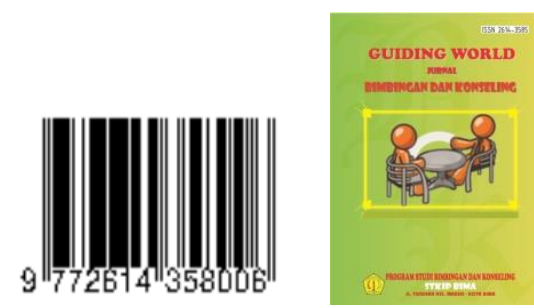

GUIDING WORLD JURNAL

BIMBINGAN DAN KONSELING

DOI: 1033627

Volume 03, Nomor 02

November 2020

E-ISSN: 2614-3585

\section{Tinjauan Perilaku Bullying}

Bullying berasal dari kata "bully" yang artinya penggertak atau orang yang menggangu orang lain yang lebih lemah. Bullying secara umum juga diartikan sebagai perpeloncoan, penindasan, pengucilan, pemalakan dan sebagainya. Perilaku bullying dilakukan dalam situasi dimana adahasrat untuk melukai, manakuti atau membuat orang lain merasa tertekan, trauma, depresi dan tidak berdaya. Menurut Olweus (dalam kutipan jurnal Kusumasari Kartika, dkk, 2019: 57) bullying merupakan masalah psikososial dengan menghina dan merendahkan orang lain secara berulang-ulang dengan dampak negatif terhadap pelaku dan korban bullying, dimana pelaku mempunyai kekuatan yang lebih dibandingkan korban. Menurut Barbara Coloroso (dalam kutipan jurnal Yuyarti, 2018: 170) bullying adalah tindakan bermusuhan yang dilakukan secara sadar dan disengaja yang bertujuan untuk menyakiti, seperti menakuti melalui ancaman agresi dan menimbulkan terror dan merupakan tindakan yang direncanakan maupun yang spontan bersifat nyata.

\section{Jenis-Jenis Perilaku Bullying}

Berdasarkan pengertian perilaku bullying di atas, maka terdapat jenis-jenis perilaku bullying. Menurut Coloroso (Yuyarti, 2018: 170) ada tiga jenis-jenis perilaku bullying yaitu sebagai berikut: 1)Perilaku Bullying Fisik: Penindasan fisik merupakan jenis bullying yang paling tampak dan paling dapat diidentifikasi diantara bentuk-bentuk penindasan lainnya, namun kejadian penindasan fisik terhitung kurang dari sepertiga insiden penindasan yang dilaporkan oleh anak. Contoh jenis penindasan secara fisik adalah sebagai berikut; memukul, mencekik, menyikut, meninju, menendang, menggigit, mencakar dan meludahi. Individu yang ditindas hingga ke posisi yang menyakitkan, merusak dan menghancurkan pakaian serta barangbarang milik individu yang tertindas. 2)Perilaku Bullying Verbal: Bullying verbal adalah bentuk penindasan yang paling umum digunakan baik oleh anak perempuan maupun anak laki-laki. Bullying verbal mudah dilakukan dan dapat dibisikan dihadapan orang dewasa serta teman sebaya tanpa terdeteksi.Perilaku bullying verbal berupa julukan nama, celaan, fitnah, kritik kejam dan pernyataan-pernyataan bernuansa ajakan seksual atau pelecehan seksual.3)Perilaku Bullying Relasional: Perilaku bullying relasional adalahperilaku bullying yang paling sulit untuk dideteksi dari luar. Bullying relasional adalah pelemahan harga diri korban bullying secara sistematis melalui pengabaian, pengecualian atau penghindaran. Perilaku bullying relasional dapat mencakup sikap-sikap yang tersembunyi seperti pandangan yang agresif, lirikan mata, helaan napas, bahu yang bergidik, cibiran, tawa mengejek dan bahasa tubuh yang kasar.

\section{Faktor Penyebab Terjadinya Perilaku Bullying}

Terjadinya perilaku bullying bukan tidak beralasan, ada banyak faktor penyebab terjadinya perilaku bullying antara lain faktor keluarga, lingkungan sekolah, teman sebaya dan lingkungan sosial.1)Lingkungan Keluarga; Pelaku perilaku bullying seringkali berasal dari keluarga yang bermasalah, misalnya sering mendapatkan hukuman dari orangtua secara berlebihan atau situasi rumah yang penuh stress, agresi dan permusuhan. 2)Lingkungan Sekolah; Pihak sekolah sering mengabaikan keberadaan bullying ini, akibatnya anak-anak sebagai pelaku bullying akan mendapatkan penguatan terhadap perilakunya untuk melakukan intimidasi terhadap individu lainnya. Perilaku bullying dapat berkembang dengan pesat dalam lingkungan sekolah dan sering memberikan masukan negatif pada individu. Misalnya 


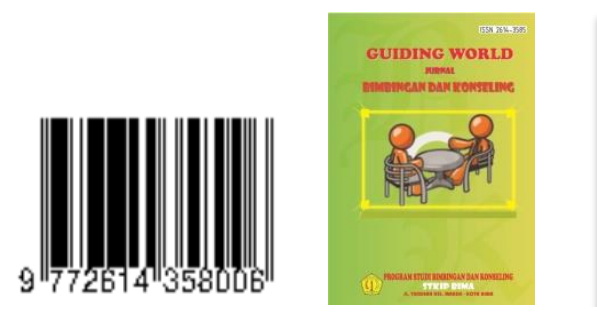

memberikan hukuman yang tidak membangun sehingga tidak mengembangkan rasa menghargai dan menghormati antar sesama angggota sekolah. 3)Kelompok Sebaya; Ketika individu berinteraksi dalam sekolah dan lingkungan rumah, individu terdorong untuk melakukan perilaku bullying. Beberapa individumelakukan perilaku bullying dalam usaha untuk membuktikan bahwa mereka bisa masuk dalam kelompok tertentu, meskipun mereka sendiri merasa tidak nyaman dengan perilaku tersebut. 4)Lingkungan Sosial: Lingkungan sosial dapat menjadi penyebab timbulnya perilaku bullying. Salah satu faktor lingkungan sosial yang menyebabkan perilaku bullying adalah kemiskinan. Individu yang hidup dalam kemiskinan akan berbuat apa saja demi memenuhi kebutuhan hidupnya, sehingga tidak heran jika di lingkungan sekolah sering terjadi pemalakan antar peserta didik.

\section{Langkah-Langkah Jika di-Bully}

a. Tetap percaya diri dan hadapi tindakan bullying dengan berani

b. Simpan semua bukti perilaku bullying yang bisa dilaporkan kepada penegak hukum (khususnya untuk cyber bullying)

c. Berbicara dan laporkan

d. Berbaurlah dengan teman-teman yang membuat kalian percaya diri dan selalu berpikir positif

e. Tetap berpikir positif

\section{Tinjauan Remaja}

Masa remaja merupakan masa peralihan antara masa kehidupan anak-anak dan masa kehidupan orang dewasa yang ditandai dengan pertumbuhan dan perkembangan biologis dan psikologis. Secara biologis ditandai dengan tumbuh dan berkembangnya seks perimer dan seks sekunder sedangkan secara psikologis ditandai dengan sikap dan perasaan, keinginan dan emosi yang labil atau tidak menentu. Menurut WHO (Badan Kesehatan Dunia), remaja adalah penduduk dalam rentang usia 10-19 tahun, menurut Peraturan Menteri Kesehatan RI Nomo 25 tahun 2014, remaja adalah penduduk dalam rentang usia 10-18 tahun dan menurut Badan Kependudukan dan Keluarga Berencana (BKKBN) rentang usia remaja adalah 10-24 tahun dan belum menikah. Masa remaja adalah masa peralihan atau masa transisi dari anak menuju masa dewasa. Pada masa remaja ini begitu pesat mengalami pertumbuhan dan perkembangan baik itu fisik maupun mental.

Menurut Hurlock (dalam kutipan jurnal Khoirul, B.H dan M. Farid, 2016), fase remaja dapat dibagi menjadi masa remaja awal dengan usia antara 13-17 tahun dan masa remaja akhir dengan usia 17-18 tahun. Masa remaja awal dan akhir menurut Hurlock memiliki karakteristik yang berbeda dikarenakan pada masa remaja akhir individu telah mencapai transisi perkembangan yang lebih mendekati dewasa.

\section{Ciri-Ciri Remaja}

Menurut Sidik Jatmika (dalam jurnal Khamim Z.P, 2017) ciri-ciri remaja dapat dibagi menjadi beberapa yaitu sebagai berikut:

a. Remaja mulai menyampaikan kebiasaannya dan haknya untuk mengemukakan pendapatnya sendiri, dapat menciptakan ketegangannya dan perselisihan dan bisa menjauhkan rema dari keluarganya. 


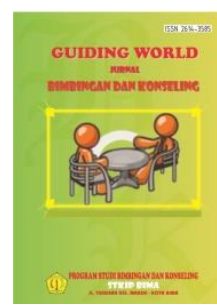

DOI: 1033627

Volume 03, Nomor 02

November 2020

E-ISSN: 2614-3585

b. Remaja lebih mudah dipengaruhi oleh teman-temannya dari pada mereka masih kanakkanak. Masa remaja berperilaku dan mempunyai kesenangan yang berbeda bahkan bertentangan dengan perilaku dan kesenangan keluarga.

c. Remaja mengalami perubahan fisik yang luar biasa, baik pertumbuhannya maupun seksualitas. Perasaan seksual yang mulai muncul bisa menakutkan, membingungkan serta menjadi sumber perasaan salah dan frustasi.

d. Remaja sering menjadi percaya diri serta emosinya yang biasanya meningkat sehingga dapat mengakibatkan sulit menerima nasehat dan pengarahan orangtua.

\section{Tugas Perkembangan Masa Remaja}

Masa remaja ini merupakan segmen kehidupan yang penting dalam siklus perkembangan individu dan merupakan masa transisi yang dapat diarahkan kepada perkembangan masa dewasa yang sehat. Apabila tugas perkembangan sosial ini dapat dilakukan dengan baik, remaja tidak akan mengalami kesulitan dalam kehidupan sosialnya serta akan membawa kebahagiaan dan kesuksesan dalam menuntaskan tugas perkembangan untuk fase-fase berikutnya.

Menurut William Kay (dalam kutipan jurnal Khamim Z.P, 2017) ada beberapa tugas perkembangan pada masa remaja adalah sebagai berikut:1)Menerima fisiknya sendiri sebagai keragaman kualitasnya, 2)Mencapai kemandirian emosional dari orangtua atau figur-figur yang mempunyai otoritas, 3)Mengembangkan keterampilan komunikasi interpersonal dan bergaul dengan teman sebaya baik secara individu maupun kelompok. 4)Menerima dirinya sendiri dan memiliki kepercayaan terhadap kemampuannya sendiri, 5)Memperkuat kemampuan mengendalikan diri atas dasar skala nilai, prinsip-prinsip atau falsafah hidup, 6)Mampu meninggalkan reaksi dan penyesuaian diri (sikap/perilaku)kekanak-kanakan.

\section{METODE}

Penelitian ini menggunakan pendekatan eksperimen. Penelitian eksperimen adalah satusatunya tipe penelitian yang lebih akurat atau teliti dibandingkan dengan jenis penelitian yang lain dalam menentukan relasi, hubungan dan sebab akibat. Penelitian eksperimen merupakan suatu penyelidikan yang dirancang sedemikian rupa, sehingga fenomena atau kejadian itu dapat diisolasi dari pengaruh lain. Dalam penelitian ini, peneliti menggunakan jenis penelitian pre-eksperimen desaign yaitu penelitian eksperimen yang pada prinsipnya menggunakan satu kelompok. Penelitian pre-experimental memiliki tiga tipe penelitian diantaranya sebagai berikut; (1) one shoot case study (studi kasus bentuk tunggal), (2) one-group pretest-posttest design (tes awal-tes akhir kelompok tunggal), dan (3) static group comparison.

Menurut Cresswell (2009) penelitian pre-eksperimen merupakan penelitian yang mengamati suatu kelompok utama dan melakukan intervensi sepanjang penelitian. Dalam rancangan ini tidak ada kelompok kontrol untuk diperbandingkan dengan kelompok eksperimen yang disebut one-group pretest-posttest design.

Penelitian pre-eksperimen (one-group pretest-posttest design), dimana peneliti memberikan perlakuan pada kelompok eksperimen tetapi sebelumnya diukur atau dites dahulu (pretest) selanjutnya setelah perlakuan kelompok diukur atau dites kembali (posttest).Design ini dapat digambarkan sebagai berikut; 


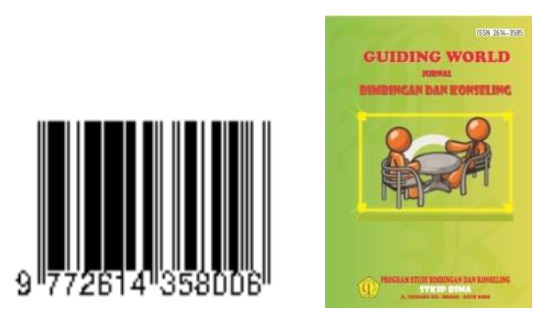

Alur penelitian one-group pretest-posttest design adalah sebagai berikut;

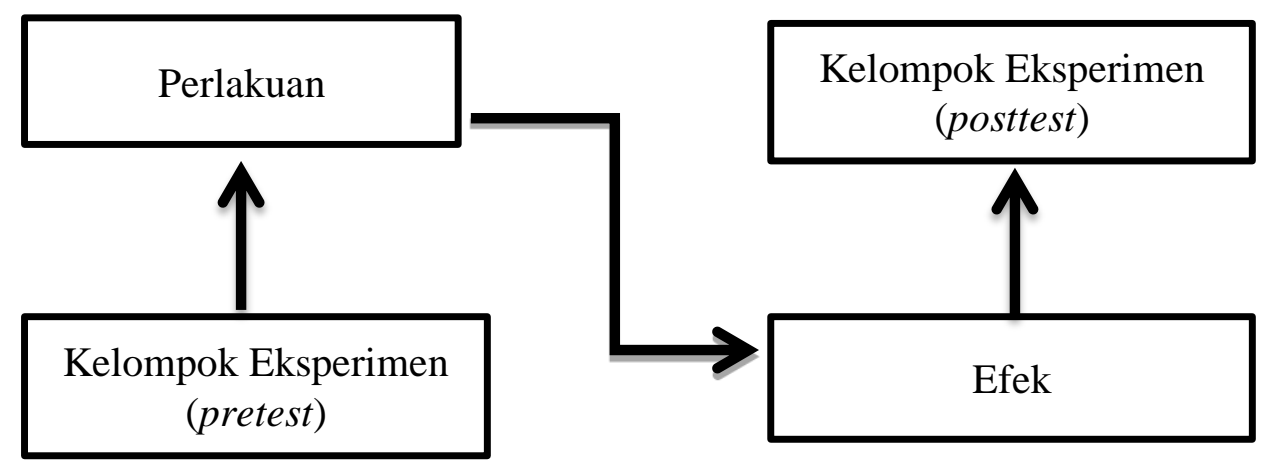

Gambar 3.1: Alur penelitian one-group pretest-posttest design

Subyek penelitian sebanyak 7 orang remaja yang memiliki perilaku bullying yang dapat memenuhi kebutuhan penelitian. Teknik pengambilan sampel pada penelitian ini menggunakan teknik purposive sampling. Metode pengumpulan data yang digunakan dalam penelitian ini adalah kuesioner/lembar penilaian diri sebagai metode utama dan observasi, wawancara sebagai metode pendukung. Pengujian hipotesis penelitian menggunakan uji statistik parametrik, yaitu uji t.

$$
\mathrm{t}=\frac{x_{1}-x_{2}}{\mathrm{~s} \sqrt{\left(\frac{1}{n_{1}}+\frac{1}{n_{2}}\right)}}
$$

Keterangan:

$\mathrm{x}_{1}$ : nilai rata-rata sebelum eksperimen

$\mathrm{x}_{2}$ : nilai rata-rata sesudah eksperimen

$\mathrm{s} \quad$ : standar deviasi gabungan

$\mathrm{n}_{1}$ : jumlah anggota sebelum eksperimen

$\mathrm{n}_{2}$ : jumlah anggota sesudah eksperimen

Kaidah keputusan:

Jika $\mathrm{t}_{\text {hitung }}>\mathrm{t}_{\text {tabel, }}$, maka $\mathrm{H}_{\mathrm{o}}$ ditolak

Jika $\mathrm{t}_{\text {hitung }} \leq \mathrm{t}_{\text {tabel }}$, maka $\mathrm{H}_{\mathrm{o}}$ diterima 


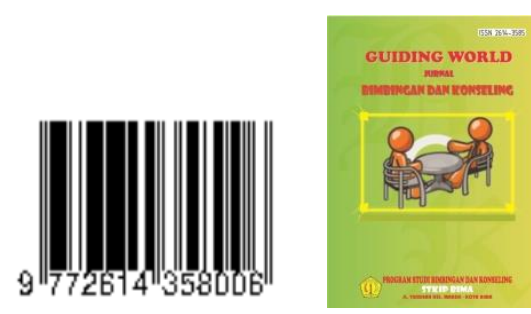

\section{HASIL PENELITIAN DAN PEMBAHASAN}

Untuk mengetahui seberapa besar efektivitas penggunaan teknik role playing untuk mengurangi perilaku bullying pada remaja di desa Rabakodo, maka peneliti melakukan analisis data pretest dan posttest.

Berikut ini adalah hasil analisis data instrumen penelitian yaitu lembar penilaian diri tentang perilaku bullying yaitu sebagai berikut:

Table 4.2: Skor Pretest dan Posttest tentang perilaku bullying

\begin{tabular}{|c|c|c|c|}
\hline \multirow{2}{*}{ NNo } & Nama & \multicolumn{2}{|c|}{ Hasil Analisis Data } \\
\cline { 3 - 4 } & Pretest & Posttest \\
\hline $\mathbf{1}$ & Aminula Bayu Maulana & 82 & 73 \\
\hline $\mathbf{2}$ & Ade Mujiburahman & 71 & 60 \\
\hline $\mathbf{4}$ & Sahrul Hidayat & 75 & 60 \\
\hline $\mathbf{5}$ & Fachrur Rozy & 47 & 45 \\
\hline $\mathbf{6}$ & Fachrur Rahman & 79 & 56 \\
\hline $\mathbf{7}$ & Khairullah & 63 & 44 \\
\hline Jumlah & Dzaky Muhtadin & 72 & 58 \\
\hline Nilai Rata-Rata & & 489 & 396 \\
\hline
\end{tabular}

Berdasarkan nilai rata-rata pada table 2 yaitu nilai rata-rata untuk pretest adalah $69,85 \%$ sedangkan nilai rata-rata untuk posttest adalah $56,57 \%$. Setelah menentukan nilai rata-rata, maka peneliti akan mencari nilai standar deviasi agar memperoleh nilai standar deviasi gabungan.

Rumus Uji t adalah sebagai berikut:

$$
t=\frac{x_{1-x_{2}}}{s \sqrt{\left(\frac{1}{n_{1}}+\frac{1}{n_{2}}\right)}}
$$



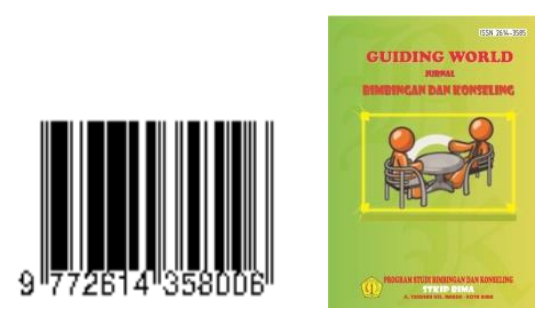

$$
\begin{aligned}
& =\frac{69,85-56,57}{10,87 \sqrt{\left(\frac{1}{7}+\frac{1}{7}\right)}} \\
& =\frac{13,28}{10,87 \sqrt{0,14+0,14}} \\
& =\frac{13,28}{10,87 \sqrt{0,28}} \\
& =\frac{13,28}{5,75} \\
& =2,309
\end{aligned}
$$

Berdasarkan hasil analisis data yang dijelaskan di atas, maka dapat peneliti simpulkan bahwa nilai $\mathrm{t}_{\text {hitung }}$ adalah 2,309.

Perilaku bullying adalah perilaku agresif secara intimidasi yang dilakukan oleh seseorang atau sekelompok orang secara berulang kali terhadap seorang korban yang tidak dapat mempertahankan diri guna untuk menyakiti atau menyingkirkan adanya kesenjangan dan adanya ketidak-seimbangan kekuatan baik secara fisik, kemampuan kognitif maupun status sosial.

Berdasarkan penjelasan di atas, maka dapat disimpulkan bahwa penggunaan teknik role playing efektif untuk mengurangi perilaku bullying pada remaja di desa rabakodo. Hasil perhitungan data dengan menggunakan uji t, maka diperoleh nilai $t_{\text {hitung }}$ adalah 2,309 dan apabila nilai $t_{\text {hitung }}$ dikonsultasikan dengan nilai $t_{\text {tabel }}$ maka nilai $t_{\text {tabel }}$ adalah 1,943 . Hal ini menandakan bahwa hipotesis nol $\left(\mathrm{H}_{0}\right)$ yang berbunyi penggunaan teknik role playing tidak efektif untuk mengurangi perilaku bullying pada remaja di desa Rabakodo sehingga hipotesis nol $\left(\mathrm{H}_{0)}\right.$ ditolak dan hipotesis alternatif $\left(\mathrm{H}_{\mathrm{a}}\right)$ yang berbunyi penggunaan teknik role playing efektif untuk mengurangi perilaku bullying pada remaja di desa Rabakodo sehingga dapat diputuskan bahwa hipotesis alternatif $\left(\mathrm{H}_{\mathrm{a}}\right)$ diterima $\left(\mathrm{t}_{\text {hitung }}>\mathrm{t}_{\text {tabel }}\right)$.

\section{PENUTUP}

Berdasarkan hasil analisis data penelitian, maka dapat disimpulkan bahwa penggunaan teknik role playing efektif untuk mengurangi perilaku bullying pada remaja di desa Rabakodo. Hal tersebut dapat dilihat dari nilai analisis data pretest adalah 489 dengan nilai rata-rata $69,85 \%$, Sedangkan nilai hasil analisis data posttest adalah 396 dengan nilai rata-rata 56,57\%. Jika dibandingkan antara nilai pretest yaitu 489 dan nilai posttest yaitu 396 dengan nilai ratarata menurunya perilaku bullying pada subyek penelitian sebanyak 93\%, sehingga dapat diputuskan bahwa hipotesis alternatif $\left(\mathrm{H}_{\mathrm{a}}\right)$ yang berbunyi penggunaan teknik role playing efektif untuk mengurangi perilaku bullying pada remaja di desa Rabakodo diterima ( $\left.t_{\text {hitung }}>t_{\text {tabel }}\right)$.

Perilaku Bullying kerap memberi dampak sosial yang buruk bagi perkembangan remaja, untuk itu peran semua pihak sangat diharapkan dalam membantu remaja agar terhindar dari dampak buruk yang berkepanjangan. Jika perilaku bullying ini dibiarkan, maka remaja akan merasa terisolir dari pergaulan, prestasi akademik akan menurun dan merasa ketakutan yang berlebihan. 


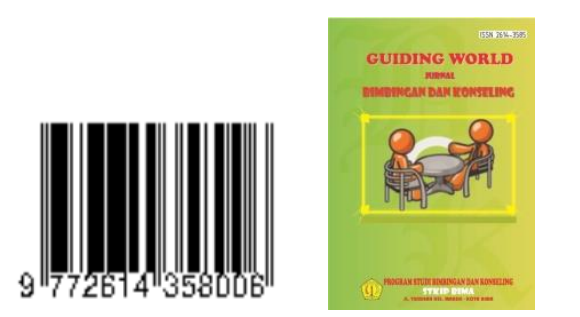

DOI: 1033627

\section{DAFTAR PUSTAKA}

Abdulsyani, 1994. Sosiologi skematikateori dan terapan, Jakarta: Bumi Aksara.

Ahmadi, A. 2004. Sosiologi Pendidikan, Jakarta: Rineka Cipta. , 2005. Psikologi Perkembangan, Jakarta: Rineka Cipta.

Dariyi, A. 2004. Psikologi Perkembangan Remaja, Bogor: Ghalia Indonesia.

Dede Rahmat dan Herdi, 2013. Bimbingan Konseling, Bandung: Remaja Rosdakara.

Effendi, OU. 1994. Ilmu Komunikasi Teori dan Praktek, Bandung: Remaja Rosda Karya.

Fachuruddin Hasballah, 2008. Psikologi Keluarga dalam Islam, Banda Aceh: Yayasan Pena Banda Aceh.

Hasan Basri, 2000. Remaja Berkualitas, Yogyakarta: Pustaka Pelajar.

Mu'awanah,dkk, 2009. Bimbingan dan Konseling Islam diSekolah Dasar, Jakarta: Bumi Aksara.

Nata, A. 2003. Manajemen Pendidikan, Jakarta: kencana

Nawawi, H. 1984. Administrasi Pendidikan, Jakarta: Gunung Agug.

Prayitno, 2004. Dasar-Dasar Bimbingan dan Konseling. Jakarta:Rineka Cipta.

Rofin, M. 2009. Remaja dalam Pelukan Dosa, Jombang: Darul Hikmah.

Suhesti, EA. 2012. Bagaimana Konselor Sekolah Bersikap, Yogyakarta: Pustaka Pelajar.

Salahudin, A. 2010. Bimbingan dan Konseling, Bandung: Pustaka Setia.

Syamsu Yusuf dan A., 2006. Juntika Nurihsan, Landasan Bimbingan \&Konseling, Bandung: Remaja Rosda Karya.

Tohrin, 2011. Bimbingan dan Konseling di Sekolah dan Madrasah, Jakarta: Rajawali Pers.

Walgito, B. 2010. Bimbingan Konseling Studi dan Karier, Yogyakarta: Andi Offset. 